ZOOLOGIA 32 (6): 438-444, December 2015

http://dx.doi.org/10.1590/S1984-46702015000600002

\title{
Factors affecting escape distance in birds
}

\section{Augusto J. Piratelli1,*, Gabriela R. Favoretto² \& Marina F. de Almeida Maximiano³}

\author{
${ }^{1}$ Departamento de Ciências Ambientais, Universidade Federal de São Carlos. Rodovia João Leme dos Santos km 110 , \\ 18086-330 Sorocaba, SP, Brazil. \\ ${ }^{2}$ Programa de Pós-Graduação em Conservação da Fauna, Laboratório de Ecologia e Conservação, Universidade Federal de \\ São Carlos. Rodovia João Leme dos Santos km 110, 18086-330 Sorocaba, SP, Brazil. \\ ${ }^{3}$ Programa de Pós-Graduação em Ecologia, Instituto Nacional de Pesquisas da Amazônia. Avenida André Araújo, \\ 69067-375 Manaus, AM, Brazil. \\ *Corresponding Author: E-mail: piratelli@ufscar.br
}

\begin{abstract}
The flight initiation distance has been used either to understand the cost-benefit trade-offs related to the risk of predation or as an important tool for wildlife managers. Although this variable is well-discussed for temperate regions, it is still poorly known in the Neotropics. Here we analyze the escape behavior of birds from southeastern Brazil, comparing an urban to a non-urban area. We tested for the influence of sites (urban vs. non-urban area), approaching (by one vs. two people), daytime (morning vs. afternoon), seasons (breeding vs. non-breeding) and body mass on the determination of the initial (FID) and final (FFD) flight distances across different bird species. We predict that FID will be greater in rural areas and under a greater threat (higher number of predators approaching) in the afternoon and in the non-breeding season. We also expect a direct relationship between body mass and FID and between FID and FFD. We sampled 11 species after measuring 331 escape behaviors, and we confirmed our predictions for sites (five species), daytime (one species) and rejected our premise about seasons for one species. Mean FID was strongly affected by body mass, and directly affected FFD. Adjustments in FID are, most likely, an important adaptive trait in urban habitats and may partially explain the predominance of species with higher ecological plasticity in cities.
\end{abstract}

KEY WORDS. Behavior; energetic; Neotropical; predation; urban.

Escape is a behavior that starts from a critical distance assessed by a prey tracking its predator. The prey must determine the predator's position and behavior and estimate the risk of remaining at a given site (COOPER 2008). Monitoring is associated with the vigilance that occurs before predator detection, allowing the prey to elaborate its decision to escape. This decision is based on the fitness costs and benefits of the behavioral alternatives in this situation: the decision to remain and take a risk vs. the decision to avoid the predator and ensure immediate survival (Wright et al. 2001).

Individuals face trade-offs in relationship to the disturbances caused by a potential threat that may increase or decrease their fitness (Frid \& Dill 2002, Moller \& Liang 2012). The timely decision of an animal to escape may directly influence feeding success because early escape decreases foraging efficiency (increasing the risk of starvation) and a delayed departure would increase the risk of death by predation. The costs (loss of foraging opportunities and risk of being predated) are balanced to achieve an optimal flight distance, thus ensuring individual reproductive success, meaning that a balance between costs and benefits has been reached in the context of effective feeding and predator avoidance (YDenberg \& Dill 1986).
Flying is one of the most widespread anti-predator responses in birds (Rocha \& Bergallo 1990 and references therein), and the distance at which an animal starts to fly due to an approaching predator is known as "initial flight distance" (FRID $\&$ Dill 2002). Several factors are known to influence the initial flight distance. These factors include taxonomic level (BLUMSTEIN 2003), predator and prey size (Товацsкi \& Dial 2000), levels of human intervention (CоOKE 1980, KenNey \& KNIGHT 1992), hunting history (LOUIS \& LE BERRE 2000), number and orientation of predators approaching (GeIsT et al. 2005), the size of the social group with which the potential prey is associated (BURGER \& Gochfeld 1991), the breeding season (BAuwens \& Thoen 1981), latitudinal gradients (Moller \& Liang 2012, Díaz et al. 2013) and the animal's level of hunger (Milinski \& HeLler 1978), which may vary across seasons as well as during the day.

The flight distance of animals is often estimated as a way of assessing human impacts on natural environments (WEARIng \& Neil 1999, Fernández-Juricic et al. 2001, Frid \& Dill 2002) either in urban or in non-urban areas. Approach by humans may be identified by birds as a predatory approach and is therefore thought to exert strong influence on animal behavior (FRID $\&$ Dill 2002), sometimes resulting in decreased reproductive 
success (Miller et al. 1998). If the initial flight distance becomes shorter when the level of human disturbance increases, this behavior can provide a rapid and easy way to evaluate the species' tolerance to human interference and to monitor the degree of disturbance in a given environment (Lin et al. 2012).

Thus, understanding the factors that jointly determine the escape distance of birds is an important tool for biodiversity conservation, as this knowledge can set limits on human actions. These studies may help the development of strategies to integrate human presence with the conservation of biodiversity, both in cities and in protected areas, supporting master and management plans, respectively. This subject has been well-discussed in temperate regions, mainly in Europe (e.g., CluCAS \& MARZlufF 2012, Møller \& Ibánez-Álamo 2012, Møller \& Liang 2012, Díaz et al. 2013), but it is poorly known for the Neotropics (but see FERNÁNDEZ-JurICIC et al. 2004, 2005, CARRETE \& TelLa 2010). In Brazil, to our knowledge, there are no previous studies focusing on this issue.

Here, we used human approach as a model to test for some factors that are thought to influence the escape distance in some Neotropical birds, assuming that this behavior, although having an innate component, may vary within populations of the same species depending on the environmental characteristics and biological factors. Our predictions are:

1) The flight distance is influenced by the intensity of human occupation, tending to decline in urban compared with nonurban areas. Populations that have been present in urban areas for generations tend to have a lower escape distance compared to those in rural habitats as the members of urban populations become used to human presence, allowing a closer approach (CоOKe 1980, Møller 2008, 2010, Carrete \& Tella 2011). The urban individuals also face a lower risk of predation because predator densities in urban areas are generally lower (DíAz et al. 2013).

2) The type of approach affects the flight distance, both in terms of the number of intruders and in terms of their positioning: the fewer the people, the smaller the escape distance. By increasing the number of people approaching a bird, we simulate an increase in the density of predators and in the risk of detection as well, thus increasing the escape distance (Frid \& Dill 2002, GeIST et al. 2005).

3) The flight distance tends to increase throughout the day. This effect is related to the individual's level of satiation: the lower the starvation, the greater the vigilance (BEDNEKoff \& Houston 1994, Olsson et al. 2000).

4) The seasons (breeding vs. non-breeding) affect the flight distance in birds. In the breeding season, high energy costs are associated with parental care, and we would expect a higher adult tolerance to intruders and a shorter escape distance (Frid \& DILL 2002).

5) Larger birds have a greater flight distance than smaller birds. Body size and body mass are closely related to the ability to avoid predation; larger birds tend to have a longer flight distance, i.e., they are less tolerant to predator approach.
This lower level of tolerance is due primarily to their greater requirements for energy in taking off from the substrate: these large birds are less agile and are more easily visually recognized by predators. For this reason, they are more vulnerable to predation than are smaller-bodied species (Blumstein 2006). If the Flight Initial Distance (FID) is related to body mass, and assuming that the energy expenditure required for takeoff is greater in larger-bodied species, then we would also expect to find a direct relationship between FID and FFD (Flight Final Distance).

\section{MATERIAL AND METHODS}

This study was conducted in the region of Sorocaba, state of São Paulo, southeastern Brazil, in both urban and non-urban areas (Fig. 1). The regional climate is classified as humid subtropical (Cwa according to Köppen's climate classification) (Alvares et al. 2014). The dry season lasts from April to September. August is the driest month (mean $=33 \mathrm{~mm}$ ), and July the coldest $\left(\right.$ mean $=18^{\circ} \mathrm{C}$ ). The rainy season, which includes the breeding season of most tropical birds (WISELSKI et al. 2000), occurs from October to March. January is the wettest month $($ mean $=235.5 \mathrm{~mm})$ and January $/$ February are the hottest months $\left(\right.$ mean $\left.=25^{\circ} \mathrm{C}\right)($ CEPAGRI 2015).
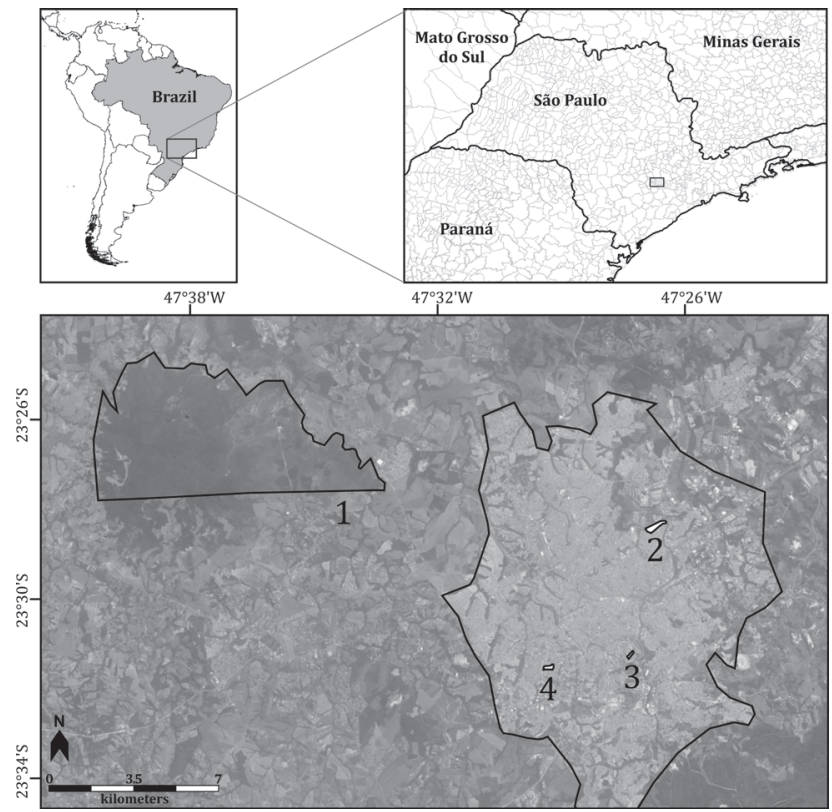

Figure 1. Map of the region of Sorocaba, southeastern Brazil, and the sampled areas. 1 = Ipanema National Forest; 2 = Parque das Águas; 3 = Parque da Biquinha; 4 = Parque da Água Vermelha.

We sampled three parks in an urban area. We sampled the park known locally as "Parque das Águas" (23⒉ $8^{\prime} 12^{\prime}$ "S, $\left.47^{\circ} 26^{\prime} 46^{\prime \prime} \mathrm{W}\right), 116.39$ ha in area and bordered by the largest 
river running through the city, the Sorocaba River; the "Parque

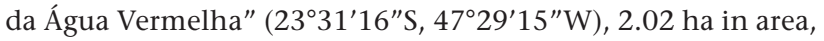

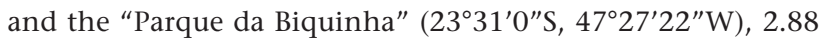
ha in area. All three parks have trees, trails, lakes and recreation areas. The first park is relatively less wooded (only $~ 3 \%$ of vegetal cover), and the landscape consists primarily of lawns, ponds, sidewalks and pathways, along with a park for playing ball sports. The other two parks are smaller than the first and host small patches of native vegetation (respectively $~ 50 \%$ and $\sim 47 \%$ of vegetal cover (Мота et al. 2014).

The non-urban area was represented by the Ipanema National Forest $\left(23^{\circ} 25^{\prime} 24^{\prime \prime} \mathrm{S}, 47^{\circ} 35^{\prime} 45^{\prime \prime} \mathrm{W}\right)$, a federal protected area of sustainable use approximately $15 \mathrm{~km}$ far from Sorocaba and approximately 5,385 ha in area (ICMBio 2015). The Ipanema National Forest is an ecotone landscape in which the matrix mixes semideciduous forest, dense and mixed rain forest and Cerrado sensu latu (Albuquerque \& Rodrigues 2000).

Data were collected from September 2011 to June 2013, in the urban areas and in the protected area. We estimated flight distances using a methodology modified from BLUMSTEIN (2003). When an individual bird was found on the ground, an observer walked at a steady speed toward this bird until it took flight. Then, using a measuring tape, we measured the distance between the observer and the place where the flight began (Flight Initial Distance - FID) and between this place and the landing position (Flight Final Distance - FFD). When a bird landed on a perch, the FFD was calculated as the square root of the sum of squares of the horizontal and vertical distances. When birds were in a group, we chose only one individual, the one closest to the observer. We did not approach alarmed birds. We consider alarmed birds that, even before our approach, exhibited alert behavior, not foraging.

Possible effects of urbanization and familiarity of birds to human presence were tested by comparing data on the same species from distinct populations living in the city and in the protected area.

We used three treatments to address the effect of human approach on flight distance: one person approaching (1S); two side-by-side (2S); and two, one a distance of $1.5 \mathrm{~m}$ behind the other (2B) The orientation of an intruder simulates a direct or tangential approach towards the prey. Birds may be better able to detect the approach of two potential predators side by side than two predators, one behind the other (GeIsT et al. 2005).

To check whether the flight distance increased throughout the day, we collected data at various times, primarily in the morning from 6 am until 9 am and also in the afternoon from $4 \mathrm{pm}$ until $6 \mathrm{pm}$. We then grouped these data in two classes: morning and afternoon.

To evaluate the premise that the escape responses of birds in the breeding season are different from those of non-breed- ing birds, we collected data from September 2011 to June 2013, covering both wet and dry seasons. We sampled four months (October/2011, February/2012, January/2013 and February/ 2013 ) in the breeding, and five months (September/2011, September/2012, April/2013, May/2013 and June/2013) in the nonbreeding season.

To check for a positive relationship between body mass and flight distance, we surveyed birds of different sizes, implying different body masses, including passerines and non-passerine birds. We used body masses of sampled bird species from the literature (DUNNING-JR 2008). Bird species taxonomy follows the CBRO (2014).

We $\log _{10}$-transformed FID, FFD and body mass to achieve normal distributions (MølLer \& LIANG 2012), selecting species having at least 10 samples and at least two replications for each factor. We used a multivariate linear regression analysis (95\% confidence intervals) to test the joint effect of all independent variables (urban x non-urban, approximation, daytime, seasons, body mass) on the dependent variables (FID and FFD).

To check for nonrandom variation in FID and FFD across species, we ran a one-way analysis of variance with log-10 transformed data (Díaz et al. 2013). We used a linear regression analysis to check for the effect of body mass on the FID and FFD (using means of FID and FFD of all individuals of the same species) and on the FID in FFD (using data for all species).

All analyses were run with R software (R Development CoRe TEAM 2008).

\section{RESULTS}

We sampled 533 records of flight distances, from which $281(53 \%)$ were in the urban area and $252(47 \%)$ in the nonurban area, totaling 57 species from 14 orders and 28 families; 30 were passerines (53\%) and 27 non-passerines (47\%). Sixteen species were sampled only in the non-urban habitat; 19 only in the city and 22 in both places. Next, we select eleven species from these 22 (meeting our criteria of having at least ten samples and at least two replications for each factor), resulting from 331 "valid" records (Appendix S1 ${ }^{1}$ ).

Five species had a significantly longer FID in the protected area: Ardea alba (Carl Linnaeus, 1758, Ardeidae) ( $\mathrm{F}=11.67, \mathrm{p}=$ 0.003), Furnarius rufus (Gmelin, 1788), Furnariidae ( $\mathrm{F}=19.8, \mathrm{p}=$ 0.025), Gallinula galeata (Lichtenstein, 1818), Rallidae ( $\mathrm{F}=8.67$, $\mathrm{p}=0.009)$, Vanellus chilensis (Molina, 1782), Charadriidae $(\mathrm{F}=$ 26.618, p = 3.93e-06) and Zenaida auriculata (Des Murs, 1847), Columbidae $(\mathrm{F}=1,796, \mathrm{p}=2.309 \mathrm{e}-07)$. One species, F. rufus, increased its FID in the breeding season ( $F=5.63, \mathrm{p}=0.000)$, (contrary to our prediction), and one species (A. alba) had a longer FID in the afternoon ( $\mathrm{F}=1.796, \mathrm{p}=2.309 \mathrm{e}-07)$. We have found no effect of the type of approach (Figs. 2-8).

\footnotetext{
${ }^{1}$ Available as Online Supplementary Material accessed with the online version of the manuscript at http://www.scielo.br/zool
} 

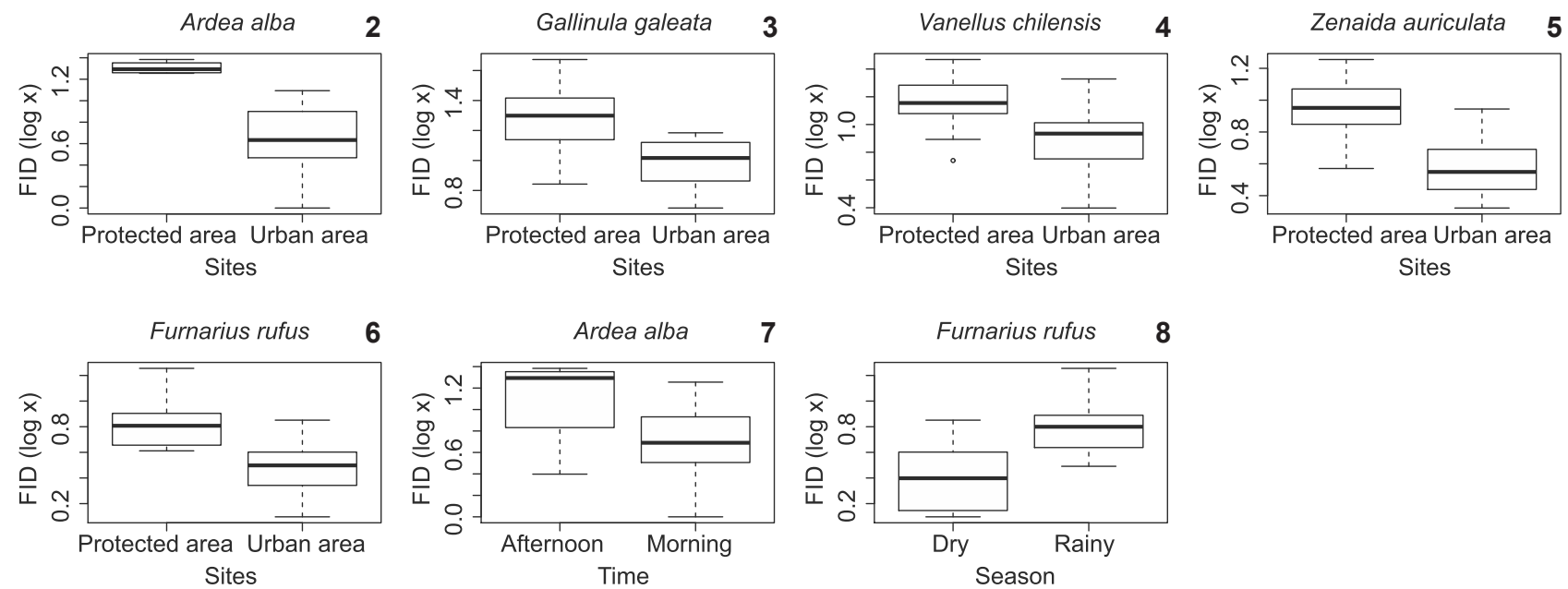

Figures 2-8. Boxplots (means and standard deviations) of FID for species having significant differences for sites (2-6), daytime (7) and seasons (8). Ardea alba, $\mathrm{F}=11.67, \mathrm{p}=0.003$; Furnarius rufus, $\mathrm{F}=19.8, \mathrm{p}=0.025$; Gallinula galeata, $\mathrm{F}=8.67, \mathrm{p}=0.009$; Vanellus chilensis, $\mathrm{F}=26.618$, $\mathrm{p}=3.93 \mathrm{e}-06$; Zenaida auriculata, $\mathrm{F}=1,796, \mathrm{p}=2.309 \mathrm{e}-07$; Furnarius rufus, $\mathrm{F}=5.63, \mathrm{p}=0.000$; Ardea alba, $\mathrm{F}=1.796, \mathrm{p}=2.309 \mathrm{e}-07$.

The sampled species differed in FID and in FFD ( $\mathrm{F}=$ $36.591, \mathrm{p}=4.09 \mathrm{e}-09)$. We found a positive and significant correlation between body mass and FID $(\mathrm{F}=8.0079, \mathrm{p}=0.0142)$ and between FID and FFD ( $\mathrm{F}=33.412, \mathrm{p}=0.0002$; smaller species had a shorter FID (Figs. 9-11).

\section{DISCUSSION}

According to our prediction, and as stressed in previous studies (e.g., MøLler \& Liang 2012), we found a decreased FID in populations of five species living in the urban area. More than half of the world's human population lives in urban areas, and this process has accelerated rapidly in Latin America (OrTEgAÁlvarez \& MacGregor-Fors 2011 and references therein). These habitats usually have high human population densities and are subject to more frequent disturbances (MøLLER 2012); faced with this situation, animals incur extreme energy expenditure through escape, which can lead to a reduction in body condition and, consequently, lower fertility rates and expectation of survival, and a population decline is expected (MølLer 2008).

Tolerance to urban areas is directly related to the choice of species habitats, resource requirements, reproductive strategies and survival rates, resulting from behavioral flexibility (the ability of the individual to adjust their behavioral decisions to different circumstances), and ecological (ability to use new features) and physiological (ability to withstand physiological stress) adaptations (MølLer 2009). Thus, reducing FID is a strategy that fits the urban characteristics, increasing tolerance to human presence and adjusting the cost-benefit relationship between risks of starvation and predation. This pattern may be common in the Neotropics, mainly for species having higher ecological plasticity and, in part, may explain the higher pres- ence of generalist species replacing specialists in urban areas.

We have not found any difference in bird's responses to the three tested types of approach. Actually, It is not clear how an increase in predator density can influence the behavior (GEIST et al. 2005) and studies on this variable are still scarce, but anti-predatory responses related to predator density may vary according to historical and ecological conditions (ABRAMs 1994).

We have detected changes in FID over a day for A. alba. The FID became longer in the afternoon, in agreement with our prediction. However, it is also possible that conditions such as availability of food resources may act more forcefully in determining the FID than time itself. If the food resource density is high, an increase in foraging time can offset the predation risk; when resources are scarce in the area, the benefits of flee and look for a new area quickly outweigh the costs to of continuing to forage (YDenberg \& Dill 1986).

One species (F. rufus) increased its FID in the breeding season. Birds would respond differently to the risk of predation during the breeding season (FrID \& DILL 2002) because escape behavior requires time and energy, which otherwise would be applied to other activities related to fitness, such as parental care. The decision to stay and defend the nest or abandon it and ensure individual survival depends on factors such as residual reproductive value (probability of future reproductive success), clutch size (species having larger offspring tend to leave the nest more easily), the offspring mortality rate, territorial behavior, and opportunistic flock formation (favoring foraging, parental care, and territorial defense) (Frid \& Dill 2002).

A robust correlation was found between body mass and mean FID. Larger species have higher FIDs than smaller ones (BLumstein 2006), and if the body mass is negatively related to escape ability, then the benefits of an early escape (longer FID) 

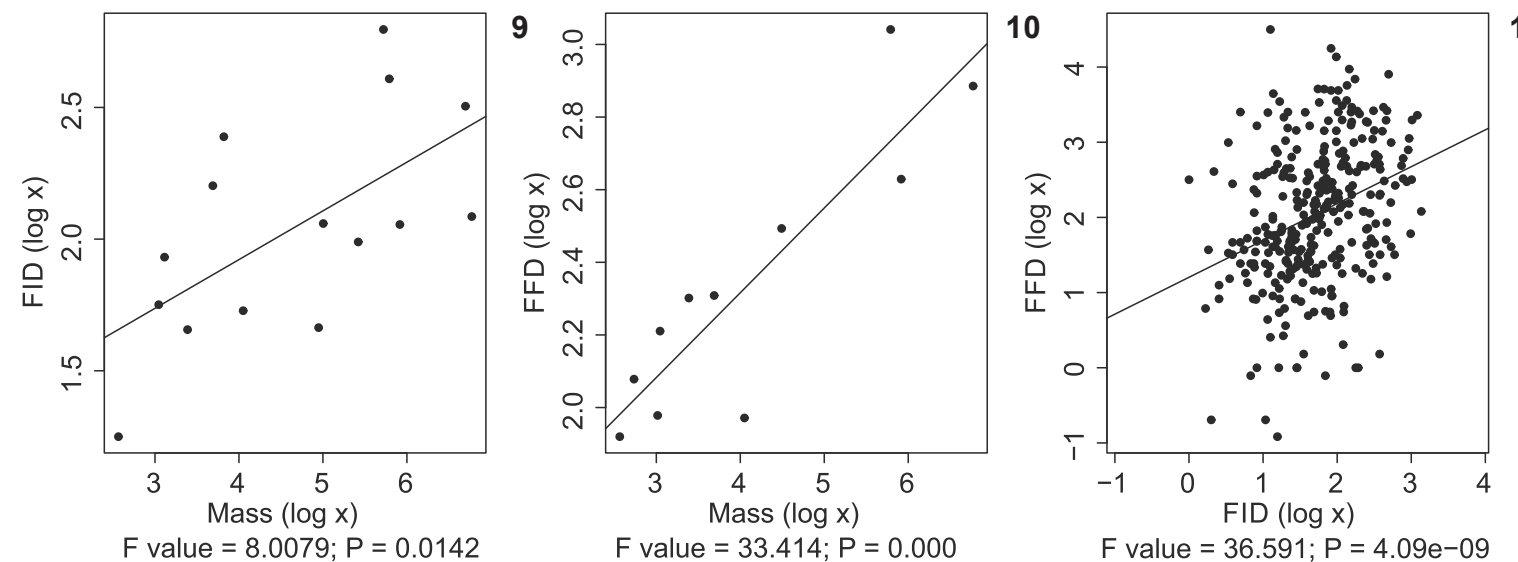

11

Figures 9-11. Linear regression for (9) Body mass x FID; (10) Body mass x FFD and (11) FID x FFD. Body mass from DuNNING-JR (2008); FID = Flight initial distance (mean for each one of the eleven sampled species); FFD = Flight final distance (mean for each one of the eleven sampled species).

will be higher for larger species than for small ones. Furthermore, the larger species are more visible to predators, and their vulnerability contributes to increase the cost of staying (LimA 1993). They also have a greater ability to detect a predator (BLumstern et al. 2005) and a higher FID as well; therefore, they are generally more vulnerable to human presence. Under intense disturbance, the fitness of the larger species can decrease more markedly by reducing the efficiency of foraging and reproductive success, tending to produce a more rapid population decline than that seen in smaller species (FernándeZ-Juricic et al. 2006, MøLLer 2008). Accordingly, large-bodied birds are likely to decline in cities.

Larger species also have a longer flying range and a higher speed shortly after takeoff (TOBALSKE \& DiAL 2000), thus requiring larger areas for survival (SCHOENER 1968), and a higher speed at the end of the runway (Tobalske \& Dial 2000), these factors can also explain their relationship to a greater FFD. Smaller species that have higher metabolic rates may be unable to tolerate long periods without landing to feed, thus rapidly returning to foraging behavior after a disturbance (LimA 1993), resulting in a shorter DFF.

Many studies focusing on factors affecting escape distance are based on optimal escape theory, which states that prey initiates flight when costs of remaining and fighting are the same (YDenberg \& Dill 1986). However, recent papers have stressed the strangeness of the costs paid to monitor an approaching predator, the Flush Early and Avoid the Rush (FEAR) hypothesis (e.g., Blumstein 2010, Samia \& Blumstein 2015), and a positive correlation between alert distance $(\mathrm{AD})$ and flight initiation distance (FID), which were not tested here. Thus, we conclude that this issue is not exhausted, and new fronts are still being opened, mainly in the Neotropics, where a gap in the knowledge of this behavioral trait still remains. As stressed before, to investigate the set of factors affecting escape distance in Neotropical birds is a valuable tool for defining public policies regarding land use, both in natural areas and in the cities.

\section{ACKNOWLEDGMENTS}

We thank the Instituto Chico Mendes de Conservação da Biodiversidade (ICMBio) for permission to work at Ipanema National Forest (Process 30005) and the Municipal Secretary of Environment in Sorocaba for allowing us to work in the urban parks. We also thank A. Bellemo, V. Cardoso, E. Kataoka, B. Gagetti, L. Cremonesi and L. Moraes for their help in the field, and Anna E. Oliveira, for help in data organization.

\section{LITERATURE CITED}

Aвrams PA (1994) The fallacies of "ratio-dependent" predation. Ecology 75(6): 1842-1850. doi: 10.2307/1939644

Albuquerque GR, Rodrigues RR (2000) Floresta Nacional de Ipanema: caracterização da vegetação em dois trechos distintos do Morro de Araçoiaba, Iperó. Scientia forestalis 58: 145-159.

Alvares CA, Stape JL, Sentelhas PC, Gonçalves Jlm, Sparovek G (2014) Koppen's climate classification map for Brazil. Meteorologische Zeitschrift 22: 711-728. doi: 10.1127/ 0941-2948/2013/0507

Baumens D, Thoen C (1981) Escape tactics and vulnerability to predation associated whit reproduction in the lizard Lacerta vivipara. Journal of Animal Ecology 50(3): 733-743. doi: $10.2307 / 4133$

Bednekoff PA, Houston AI (1994) Avian daily foraging patterns: effects of digestive constraints and variability. Evolutionary Ecology 8(1): 36-52. doi: 10.1007/BF01237664

Blumstein DT (2003) Flight initiation distance in birds is dependent on intruder starting distance. Journal of Wildlife Managment 67(4): 852-857. doi: 10.2307/3802692 
Blumstern DT (2006) Developing an evolutionary ecology of fear: how life history and natural history traits affect disturbance tolerance in birds. Animal Behavior 71(2): 389399. doi: 10.1016/j.anbehav.2005.05.010

BLUMSTEIN DT (2010) Flush early and avoid the rush: a general rule of antipredator behavior? Behavioral Ecology 21(3): 440-442. doi: 10.1093/beheco/arq030

Blumstein DT, Fernández-Juricic E, Zollner PA, Garity SC (2005) Inter-specific variation in avian responses to human disturbance. Journal of Applied Ecology 42(5): 943-953. doi: 10.1111/j.1365-2664.2005.01071.x

Burger J, Gochfeld M (1991) Human distance and birds: tolerance and response distances of resident and migrant species in India. Environmental Conservation 18(2): 158165. doi: 10.1017/S0376892900021743

Carrete M, Tella JL (2010) Individual consistency in flight initiation distances in burrowing owls: a new hypothesis on disturbance induced habitat selection. Biology Letters 6(2): 167-170. doi: 10.1098/rsbl.2009.0739

Carrete M, Tella JM (2011) Inter-individual variability in fear of humans and relative brain size of the species are related to contemporary urban invasion in birds. PLoS One 6(4): e18859. doi: 10.1371/journal.pone.0018859

CBRO (2014) Listas das aves do Brasil. Comitê Brasileiro de Registros Ornitológicos, $11^{\text {th }}$ ed. Available online at: http:/ /www.cbro.org.br [Accessed: 07/10/2014]

CEPAGRI (2015) Clima dos Municípios Paulistas: Sorocaba. Campinas, Centro de Pesquisas Meteorológicas e Climáticas Aplicadas à Agricultura. Available online at: http://www.cpa.unicamp.br/ outras-informacoes/clima_muni_584.html [Accessed:21/04/2015]

Clucas B, Marzluff JM (2012) Attitudes and actions toward birds in urban areas: human cultural differences influence bird behavior. The Auk 129(1): 8-16. doi: 10.1525/auk.2011.11121

COoKe AS (1980) Observations on how close certain passerine species will tolerate an approaching human in rural and suburban areas. Biological Conservation 18(2): 85-88. doi: 10.1016/0006-3207(80)90072-5

COOPER WE (2008) Visual monitoring of predators: occurrence, cost and benefit for escape. Animal Behaviour 76(4): 13651372. doi: 10.1016/j.anbehav.2008.03.029

Díaz M, Møller AP, Flensted-Jensen E, Grim T, Ibáñez-Álamo JD, Jokimaki J, Markó G, Tryjanowski P (2013) The Geography of Fear: A Latitudinal Gradient in Anti-Predator Escape Distances of Birds across Europe. PLoS One 8(5): e64634. doi: 10.1371/journal.pone.0064634

Dunning-JR JB (2008) CRC Handbook of Avian Body Masses. Boca Raton, CRC Press, 655p.

FernándeZ-Juricic E, Jimenez MD, Lucas E (2001) Alert distance as an alternative measure of bird tolerance to human disturbance: implications for park design. Environmental Conservation 28(3): 263-269. doi: 10.1017/S0376892901000273

Fernández-Juricic E, Vaca R, Schroeder N (2004) Spatial and temporal responses of forest birds to human approaches in a protected area and implications for two management strategies. Biological Conservation 117: 407-416. doi: 10.1016/j.biocon.2003.02.001

Fernández-Juricic E, Venier MP, Renison D, Blumstein DF (2005) Sensitivity of wildlife to spatial patterns of recreationist behavior: a critical assessment of minimum approaching distances and buffer areas for grassland birds. Biological Conservation 125: 225-235. doi: 10.1016/j.biocon.2005.03.020

Fernández-Juricic E, Blumstein DT, Abrica G, Manriquez L, Adams LB, Adams R, Daneshrad M, Rodriguez-Prieto I (2006) Relationships of anti-predator escape and post-escape responses with body mass and morphology: a comparative avian study. Evolutionary Ecology Research 8: 731-752.

FrID A, Dill LM (2002) Human-caused disturbance stimuli as a form of predation risk. Conservation Ecology 6(1): 11. Available online at: http://www.consecol.org/vol6/iss1/ art11/[Accessed: 21/04/2015]

Geist C, LiaO J, Libby S, Blumstein DT (2005) Does intruder group size and orientation affect flight initiation distance in birds? Animal Biodiversity and Conservation 28(1): 69-73.

ICMBIo (2015) Flona de Ipanema. Available online at: http:// www.icmbio.gov.br/portal/biodiversidade/unidades-deconservacao/biomas-brasileiros/mata-atlantica/unidades-deconservacao-mata-atlantica/2191-flona-de-ipanema.html? highlight=WyJpcGFuZW1hIl0= [Accessed: 23/04/2015]

KenNey SP, KNIGHT RL (1992) Flight distances of Black-Billed Magpies in different regimes of human density and persecution. The Condor 94(2): 545-547. doi: 10.2307/1369231

LimA SL (1993) Ecological and evolutionary perspectives on escape from predatory attack: a survey of North American birds. Wilson Bullettin 105(1): 1-47.

Lin T, Coppack T, Lin QX, Kulemeyer C, Schmidt A, Behm H, Luo T (2012) Does avian flight initiation distance indicate tolerance towards urban disturbance? Ecological Indicator 15(1): 30-35. doi: 10.1016/j.ecolind.2011.09.018.

Louis S, Le Berre M (2000) Adjustment in flight distance from humans by Marmota marmota. Canadian Journal of Zoology 78: 556-563.

Milinski M, Heller R (1978) Influence of a predator on the optimal foraging behaviour of sticklebacks (Gasterosteus aculeatus L.). Nature 275: 642-644. doi: 10.1038/275642a0

Miller SG, Knight RL, Miller CK (1998) Influence of recreational trails on breeding bird communities. Ecological Applications 8: 162-169. doi: 10.1890/1051-0761

MøLler AP (2008) Flight distances of urban birds, predation and selection for urban life. Behavioral Ecology Sociobiology 63(1): 63-75. doi: 10.1007/s00265-008-0636-y

MøLler AP (2009) Successful city dwellers: a comparative study of the ecological characteristics of urban birds in the Western Palearctic. Oecologia 159(4): 849-858. doi: 10.1007/s00442008-1259-8

Møller AP (2010) Interspecific variation in fear responses predicts urbanization in birds. Behavioral Ecology 21(2): 
365-371. doi: 10.1093/beheco/arp199

Møller AP (2012) Urban areas as refuges from predators and flight distance of prey. Behavioral Ecology 23(5): 10301035. doi: 10.1093/beheco/ars067

MølLER AP, IBÁÑEZ-ÁLAMo JD (2012) Escape behaviour of birds provides evidence of predation being involved in urbanization. Animal Behaviour 84(2): 341-348. doi: 10.1016/j.anbehav.2012.04.030

Møller AP, Liang W (2012) Tropical birds take small risks. Behavioral Ecology 24(3): 267-272. doi: 10.1093/beheco/ ars163

Mota MT, Leite EC, Sola F (2014) Parques em paisagem urbana e seu potencial para implantação de áreas protegidas - estudo de caso no sudeste do Brasil. Revista Brasileira de Arborização Urbana 9(1): 59-77.

Olsson O, Wiktander U, Nilsson SG (2000) Daily foraging routines and feeding effort of a small bird feeding on a predictable resource. Proceedings Royal Society 267(1451): 1457-1461. doi: 10.1098/rspb.2000.1164

Ortega-Álvarez R, MacGregor-Fors I (2011) Dusting-off the file: A review of knowledge on urban ornithology in Latin America. Landscape and Urban Planning 101(1): 1-10. doi: 10.1016/j.landurbplan.2010.12.020

R Development Core Team (2008) R: a language and environment for statistical computing. Vienna, R Foundation for
Statistical Computing.

Rocha CFD, Bergallo HG (1990) Thermal biology and flight distance of Tropidurus oreadicus (Sauria Iguanidae) in an area of Amazonian Brazil. Ethology Ecology \& Evolution 2(3): 263-268. doi: 10.1080/08927014.1990.9525411

Samia DSM, Blumstein DT (2015) Birds Flush Early and Avoid the Rush: An Interspecific Study. PLoS ONE 10(3): e0119906. doi: 10.1371/journal.pone.0119906

Schoener TW (1968) Sizes of Feeding Territories among Birds. Ecology 49(1): 123-141. doi: 10.2307/1933567

Tobalske BW, Dial KP (2000) Effects of body size on take-off flight performance in the Phasianidae (Aves). The Journal Experimental Biology 203: 3319-3332.

Wearing S, NeIL J (1999) Ecotourism: Impacts, Potentials and Possibilities. Oxford, Butterworth-Heinemann, 285p.

Wikelski M, Haum M, Wingfield JC (2000) Seasonality of reproduction in a Neotropical rain forest birds. Ecology 81(9): 2458-2472. doi: 10.1890/0012-9658

Wright J, Berg E, de Kort SR, Khazin V, Maklakov AA (2001) Cooperative sentinel behaviour in the Arabian babbler. Animal Behaviour 62: 973-979. doi: 10.1006/anbe.2001.1838

Ydenberg RC, Dill LM (1986) The economics of fleeing from predators. Advences in the Study of Behavior 16: 229249. doi: 10.1016/S0065-3454(08)60192-8

Submitted: 2 July 2015

Received in revised form: 8 October 2015

Accepted: 15 November 2015

Editorial responsibility: Luís Fábio Silveira 